\title{
SIKAP WIRAUSAHA MAHASISWA PADA PERKULIAHAN BIOTEKNOLOGI BERMUATAN BIOENTREPRENEURSHIP
}

\author{
Ismail Fikri Natadiwijaya ${ }^{1,2}$, Adi Rahmat ${ }^{3}$, Sri Redjeki ${ }^{3}$, Sri Anggraeni $^{3}$ \\ 1. Program studi pendidikan IPA, Sekolah Pascasarjana Universitas Pendidikan Indonesia, \\ Jl.Dr.Setiabudi No.229 Bandung, Indonesia \\ 2. Program studi pendidikan biologi, Universitas Wiralodra, Jl.Ir.H.Juanda.Km.3, Indramayu, \\ Indonesia \\ 3. Departemen Pendidikan Biologi, Universitas pendidikan Indonesia, Jl.Dr.Setiabudi No.229 \\ Bandung.Indonesia \\ Email: fikrinatadiwijaya@yahoo.com ${ }^{1}$,adirahmat@upi.edu ${ }^{3}$
}

\begin{abstract}
Citasi: Natadiwijaya, I.F., Rahmat, A., Redjeki S., Anggraeni, S. 2018. Sikap Wirausaha Mahasiswa pada Perkuliahan Bioteknologi Bermuatan Bioentrepreneurship. Mangifera Edu volume 3 Nomor 1, Juli 2018. Hal 40-51
\end{abstract}

\begin{abstract}
ABSTRAK
Penelitian ini bertujuan untuk mengetahui sikap wirausaha mahasiswa pada program perkuliahan bioteknologi bermuatan bioentrepreneurship. Satu kelompok diberi perlakuan, dan selanjutnya diobservasi hasilnya. Satu kelas mahasiswa yang mengontrak mata kuliah bioteknologi semester genap 2016/2017 terlibat sebagai subjek penelitian. Instrumen yang digunakan adalah 50 item angket sikap wirausaha yang kemudian diberi skor serta dihitung nilai total rata-ratanya, dan penilaian sosialisasi produk, dimana kegiatan sosialisasi yang telah dilakukan kemudian didokumentasikan, lalu dinilai dengan cara pemberian skor berdasarkan kriteria pada rubrik yang telah ada. Pada penelitian ini didapatkan nilai sikap wirausaha mahasiswa yang dijaring melalui instrumen termasuk kategori tinggi. Sehingga dapat disimpulkan bahwa sikap wirausaha mahasiswa juga dapat memiliki nilai yang tinggi apabila dilatih melalui program bioteknologi bermuatan bioentrepreneurship.Secara umum nilai yang ada telah menunjukkan bahwa sikap wirausaha mahasiswa telah mencukupi sebagai bagi mereka menjadi guru biologi yang berjiwa wirausaha. Melalui angket respon, kebanyakan mahasiswa menyatakan bahwa perkuliahan Bioteknologi bermuatan bioentrepreneurship dapat membuat mereka memiliki sikap wirausaha yang baik, lebih menyadari besarnya kaitan antara bioteknologi dengan kewirausahaan, mampu membuat produk dan mensosialisasikannya, serta dapat meningkatkan minat terhadap bioteknologi.Berdasarkan hasil penelitian ini, maka dapat diajukan beberapa saran, yaitu diperlukannya pendampingan supaya produk-produk yang dihasilkan dapat terjual. Produk yang terjual tersebut dapat memberikan manfaat finansial bagi mahasiswa sehingga diharapkan dapat menjaga atau bahkan meningkatkan sikap wirausaha mahasiswa ke depannya.
\end{abstract}

Kata Kunci : Bioentrepreneurship, Sikap Wirausaha, Bioteknologi

\section{PENDAHULUAN}

Indonesia memiliki jumlah penduduk yang besar dan merupakan negara keempat di dunia dengan penduduk terbesar. Sampai dengan tahun 2015, tercatat jumlah penduduk 
Indonesia adalah sebesar 254,9 juta jiwa (BPS, 2015). Namun di sisi lain dengan jumlah penduduk yang besar, pemerintah Indonesia kerap menghadapi berbagai permasalahan sosial yang besar yakni dalam penyediaan sarana pendidikan, pangan dan sandang, lapangan pekerjaan dan masalah lainnya. Menurut data BPS (2015), jumlah pengangguran pada Agustus 2015 sebesar 7,56 juta orang dari total angkatan kerja sebesar 122,40 juta orang. Fakta menunjukkan bahwa sampai sebanyak 83 persen lulusan perguruan tinggi bekerja sebagai pegawai (BPS,2015). Lulusan perguruan tinggi cenderung menjadi pencari kerja dan sangat sedikit yang menjadi pencipta lapangan kerja.Sebagian besar lulusan merasa tidak siap untuk membuka lapangan pekerjaan bagi dirinya sendiri atau menjadi wirausahawan(Ciputra,2010).Pendidikan Biologi tingkat strata 1 (S1) di Universitas merupakan salah satu jenis pendidikan formal yang ada di Indonesia, dimana pada saat ini diarahkan memiliki kemampuan mengembangkan kewirausahaan yang berkaitan dengan biologi (Direktorat Pembelajaran dan Kemahasiswaan BELMAWADIKTI, 2013), oleh karena itu diperlukan program perkuliahan yang dapat melatih sikap wirausaha mahasiswa.

Kewirausahaan dapat dikembangkan salah satunya melalui penciptaan produkproduk biologi pada mata kuliah yang bersifat aplikatif seperti Bioteknologi (Collet \& Wyatt, 2005). Menurut Acquaah (2004) bioteknologi dalam arti luas adalah beberapa teknik yang menggunakan organisme hidup atau prosesnya untuk membuat atau memodifikasi produk, guna meningkatkan pemanfaatan tumbuhan dan hewan atau untuk mengembangkan mikroorganisme untuk tujuan khusus. Oleh karena itu penting untuk dikembangkan perkuliahan yang membuat mahasiswa dapat menghubungkan konsep-konsep Bioteknologi pada peluang berwirausaha di Indonesia. Pengintegrasian muatan kewirausahaan kedalam bidang ilmu hayati (Biologi/Bioteknologi) dikenal dengan istilah bioentrepreneurship. Pendidikan bioentrepreneurship adalah suatu program pendidikan yang dirancang untuk mengajarkan pengetahuan, keterampilan dan sikap yang dibutuhkan bagi seorang wirausahawan yang tertarik kepada komersialisasi produk ilmu hayati (Langer, 2014). Berbagai metode serta pendekatan telah diketahui dapat melatih sikap wirausaha mahasiswa dalam bidang sains, yaitu Blending learning (Radu, 2015), Techno-Entrepreneurship (Farzin, 2015), Bioneering (Collet \& Wyatt, 2005), discovery/Inquiry (Ibrohim,2015), dan EnSciT/Entrepreneural Science Thinking (Buang, 2009). Hasil studi tentang bioentrepreneur menunjukkan bahwa bioentrepreneurship dapat meningkatkan keterampilan proses siswa (Mutia \& Tumisem, 2015), dapat meningkatkan sikap wirausaha siswa pada pembelajaran 
pengetahuan lingkungan (Mulyaningrum, 2014), dan meningkatkan keahlian teknis dan komersial (Collet \& Wyatt, 2005). Bioentrepreneurship dapat diajarkan di universitas, baik sebagai program khusus ataupun program yang terintegrasi dengan mata kuliah, baik untuk tingkat S-1, S-2, ataupun S-3 (Meyers \&Hurley, 2008; Back 2008, Kjelstrom 2012).Hasil studi lain menunjukkan bahwa bioteknologi dapat dipadukan dengan kewirausahaan (Oliver, 2004).Melalui literatur diatas, sikap wirausaha dalam bidang sains dapat dilatih melalui bioentrepreneur atau metode lain, akan tetapi bagaimana sikap wirausaha calon guru pada pembelajaran yang lebih spesifik yaitu bioteknologi yang diberi muatan bioentrepreneurship saat ini belum diketahui.

Pada program ini, telah dikembangkan program perkuliahan bioteknologi bermuatan bioentrepreneurship. Perkuliahan bioteknologi ini terdiri dari empat fase, yaitu fase pembentukan konsep, fase kreativitas, fase produksi, dan fase sosialisasi. Tiga fase pertama dibangun berdasarkan teori yang diungkapkan oleh Heidack (Crispeels, 2008) yang menyebutkan bahwa untuk mempertemukan semua aspek yang terkait dengan entrepreneurship, program pendidikan di universitas haruslah berdasarkan kepada konsep tiga fase. Konsep ini tersusun secara berurutan yaitu fase pertama belajar berbasis pengetahuan atau dasar-dasar dalam entrepreneurship, fase kedua mengaplikasikan pengetahuan yang telah diperoleh dalam studi kasus, dan fase ketiga adalah pengetahuan diaplikasikan dan pengalaman/pengetahuan diperoleh dari dunia nyata.Pengalaman dari dunia nyata tersebut antara lain melalui pengembangan sumber daya lokal. Fase ketiga pada perkuliahan ini berupa pembuatan produk, menurut Collet dan Wyatt (2005) dalam pendidikan bioentrepreneurship mahasiswa haruslah membuat suatu produk bioteknologi berdasarkan ilmu teknis yang dikuasai dan hasil-hasil penelitian yang relevan. Sedangkan fase tambahan, yakni fase keempat yaitu sosialisasi dibangun berdasarkan pendapat York, McCarthy \& Darnold (2008), yaitu program pengembangan Pendidikan bioentrepreneurship yang baik adalah program yang memasukkan "soft skill" dalam kurikulum pembelajarannya, seperti komunikasi, penyelesaian konflik, team building/pembangunan tim, optimisme, kontrol diri dan kemampuan berempati.

Perkuliahan bioteknologi ini pada tiap fasenya dirancang untuk membangun sikap wirausaha mahasiswa.Oleh karena itu pada penelitian ini ingin diketahui bagaimana sikap wirausaha mahasiswa pada perkuliahan Bioteknologi bermuatan Bioentrepreneurship. 


\section{METODE PENELITIAN}

Jenis penelitian ini bersifat pre-experimental design tipeone-shot case study. Desain dalam penelitian eksperimen model ini dapat digambarkan seperti berikut (Fraenkel \& Wallen,2007):

\begin{tabular}{|c|l|}
\hline \multirow{2}{*}{ X o } & $\mathrm{X}=$ Perlakuan yang diberikan (Variabel independen) \\
\cline { 2 - 2 } & $\mathrm{O}=$ Observasi (Variabel dependen) \\
\hline
\end{tabular}

Desain itu dapat dibaca sebagai berikut: terdapat suatu kelompok diberi perlakuan, dan selanjutnya diobservasi hasilnya.

Instrumen yang digunakan adalah: 1) Angket skala likert untuk menjaring sikap wirausaha, berisi sejumlah pertanyaan $(n=50)$ dengan pilihan sangat setuju, setuju , netral, tidak setuju, dan sangat tidak setuju, kemudian pilihan jawaban diberi skor serta dihitung nilai total rata-ratanya. Data yang didapatkan berupa data kuantitatif (angka persentase) yang kemudian diinterpretasikan kedalam kategori Rendah/sedang/tinggi. 2) Penilaian sosialisasi produk, dimana kegiatan sosialisasi yang telah dilakukan kemudian didokumentasikan. Data yang didapatkan berupa data kualitatif (foto dan video kegiatan) dan data kuantitatif (angka persentase).Data kuantitatif didapat melalui pemberian skor terhadap berbagai kegiatan sosialisasi yang telah dilaksanakan.Pemberian skor mengacu kepada kriteria skoring rubrik yang telah ada.Data-data kuantitatif yang ada kemudian disajikan dalam bentuk grafik, sedangkan data kualitatif disajikan dalam bentuk gambar serta penjelasan naratif.

Pembelajaran dilaksanakan selama 14 kali pertemuan, yang terbagi menjadi empat (4) fase.Setiap fase berisi strategi pembelajaran yang menunjang terhadap pembentukan sikap kewirausahaan mahasiswa.Adapun bentuk program pembelajaran bioteknologi bermuatan bioentrepreneurship yang dilaksanakan beserta indikator sikap wirausaha dan alat instrumen pengukurnya adalah sebagai berikut.

Tabel 1. Bentuk program pembelajaran bioteknologi bermuatan bioentrepreneurship yang dilaksanakan beserta indikator sikap wirausaha dan alat instrument pengukurnya

\begin{tabular}{|l|l|}
\hline Strategi & Indikator sikap Wirausaha yang dikembangkan dan kode \\
\hline Fase 1 (Pertemuan 1-6) & Keorisinilan : Mengetahui banyak (ORI-1) \\
\hline $\begin{array}{l}\text { Pada fase ini mahasiswa } \\
\text { membangun konsep bioteknologi } \\
\text { melalui suatu kegiatan mengkaji } \\
\text { teori, mengkaji aplikasi bioteknologi } \\
\text { (produk dan kewirausahaannya) } \\
\text {,mengkaji artikel, diskusi dan } \\
\text { presentasi. }\end{array}$ & $\begin{array}{l}\text { Berorientasi laba dan hasil : mampu menghitung } \\
\text { peuntungan }\end{array}$ \\
\end{tabular}




\begin{tabular}{|c|c|}
\hline \multicolumn{2}{|l|}{ Fase 2 (Pertemuan 7-8) } \\
\hline \multirow{6}{*}{$\begin{array}{l}\text { Pada fase ini, mahasiswa } \\
\text { mengaplikasikan skema kognitif } \\
\text { yang telah terbentuk menjadi suatu } \\
\text { ide dan desain produk bioteknologi } \\
\text { berbahan sumber daya lokal. Pada } \\
\text { fase ini terbagi menjadi } 4 \text { langkah } \\
\text { yaitu:Persiapan, } \\
\text { Inkubasi,Iluminasi,Verifikasi, }\end{array}$} & Berorientasi laba dan hasil :Berorientasi laba "BLH-1) \\
\hline & Keorisinilan :Inovatif ${ }^{1}(\mathrm{ORI}-2)$ \\
\hline & Keorisinilan : Kreatif $^{1}($ ORI-3) \\
\hline & $\begin{array}{l}\text { Berorientasi masa depan : Memiliki pandangan ke } \\
\text { masa depan }^{1}(\text { BMD-1) }\end{array}$ \\
\hline & Keorisinilan : mampu mengemas produk ${ }^{2}$ \\
\hline & $\begin{array}{l}\text { Keorisinilan : mampu menawarkan produk secara } \\
\text { kreatif }^{2}\end{array}$ \\
\hline \multicolumn{2}{|l|}{ Fase 3 (Pertemuan 9-10) } \\
\hline \multirow{3}{*}{$\begin{array}{l}\text { Pada fase ini mahasiswa membuat } \\
\text { produk nyata berdasarkan rancangan } \\
\text { yang telah dibuat.Pada fase ini } \\
\text { kegiatan membuat produk } \\
\text { dilaksanakan di luar jam perkuliahan } \\
\text { sedangkan proses pembimbingan } \\
\text { dan evaluasi dilaksanakan pada jam } \\
\text { KBM. }\end{array}$} & $\begin{array}{l}\text { Kepemimpinan : Bertindak sebagai pemimpin }{ }^{1} \text { (KEP- } \\
\text { 1) }\end{array}$ \\
\hline & $\begin{array}{l}\text { Keorisinilan : Fleksibel dalam membuat produk }{ }^{1} \text { (ORI- } \\
\text { 4) }\end{array}$ \\
\hline & $\begin{array}{l}\text { Berorientasi laba dan hasil :Ketekunan, ketabahan, } \\
\text { tekad, kerja keras }{ }^{1} \text { (BLH-2) }\end{array}$ \\
\hline Strategi & 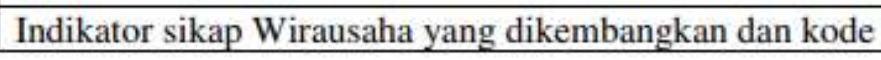 \\
\hline \multicolumn{2}{|l|}{ Fase 4 (Pertemuan 11-12) } \\
\hline \multirow{8}{*}{$\begin{array}{l}\text { Pada fase ini mahasiswa } \\
\text { menawarkan produk, kemudian } \\
\text { mengumpulkan pandangan } \\
\text { masyarakat tentang produk yang } \\
\text { dihasilkan, baik dari aspek biaya, } \\
\text { pemasaran ataupun manfaatnya } \\
\text { kemudian dianalisis dan } \\
\text { dipresentasikan hasilnya didepan } \\
\text { kelas. }\end{array}$} & Kepemimpinan : Muda \\
\hline & $\begin{array}{l}\text { Kepemimpinan : Mampu menerima saran dan kritikan }{ }^{1} \\
\text { (KEP-3) }\end{array}$ \\
\hline & Percaya diri : Percaya diri ${ }^{1}$ (PD) \\
\hline & Pengambil Risiko : Mau mengambil risiko ${ }^{1}$ (RIS-1) \\
\hline & Pengambil risiko : Suka tantangan ${ }^{1}$ (RIS-2) \\
\hline & Pengambil risiko :berani mensosialisasikan produk ${ }^{2}$ \\
\hline & Pengambil risiko: mampu mengetahui target potensial \\
\hline & Kepemimpinan : mensikapi dengan positif tanggapan \\
\hline
\end{tabular}

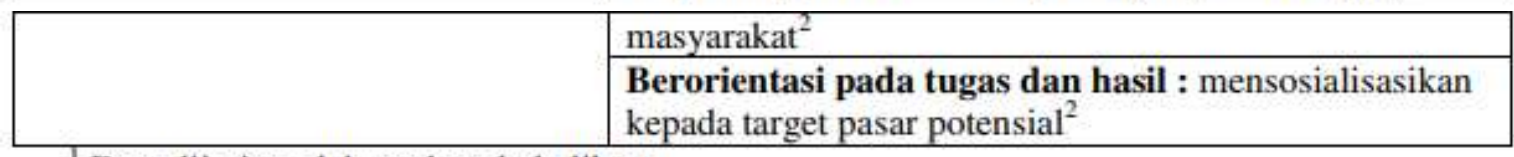

${ }^{\mathrm{T}}$ Data dijaring oleh angket skala likert

${ }^{2}$ Data dijaring oleh penilaian sosialisasi produk

\section{HASIL DAN PEMBAHASAN}

Pada penelitian ini didapatkan nilai rata-rata sikap wirausaha mahasiswa melalui tes termasuk kategori tinggi $(72,8 \%)$. Nilai sikap wirausaha dijaring melalui dua macam instrumen, yaitu angket sikap wirausaha dan penilaian sosialisasi produk.Adapun nilai sikap wirausaha mahasiswa per indikator melalui angket sikap wirausaha ditunjukkan sebagai berikut. 


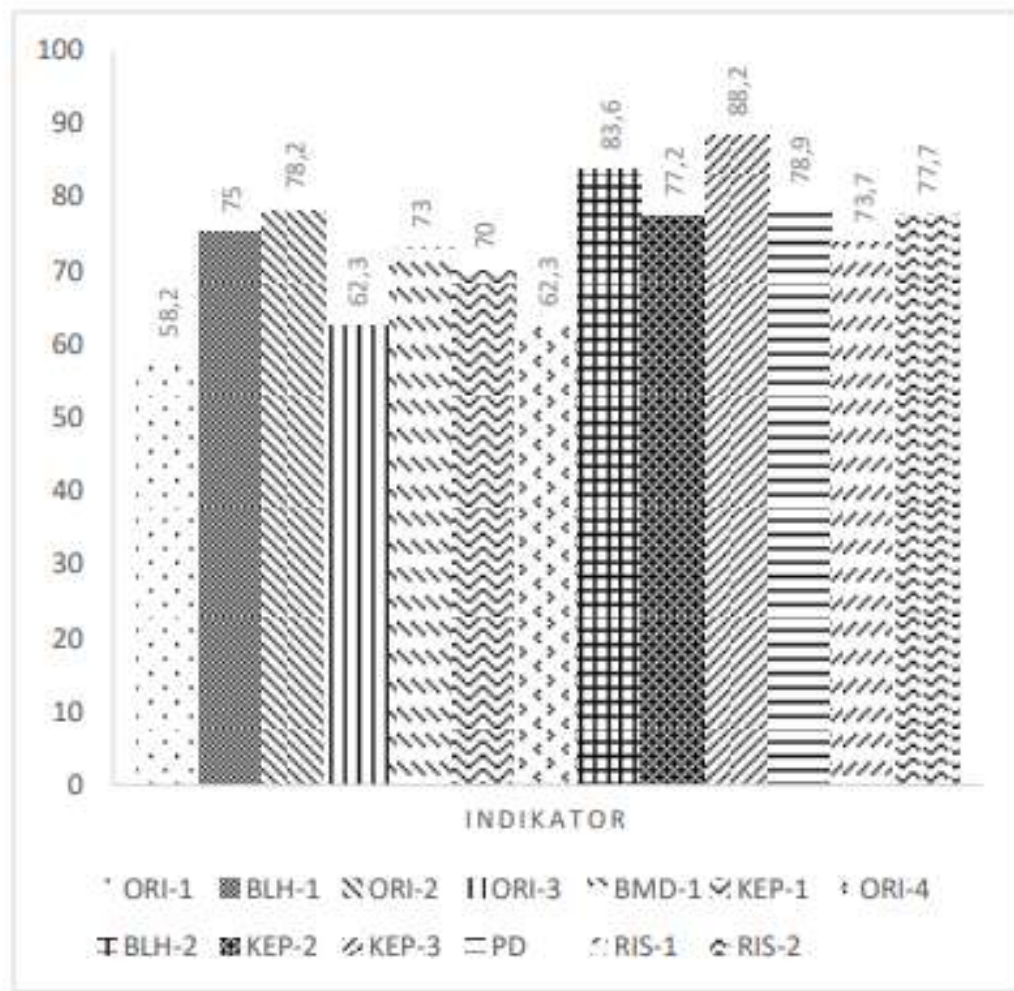

\section{Gambar 1. Nilai sikap wirausaha mahasiswa per indikator melalui angket sikap wirausaha}

Sikap wirausaha mahasiswa menunjukkan bahwa rata-rata indikator sikap wirausaha berada pada kategori tinggi (73,7\%). Antar indikator nilainya relatif tidak jauh berbeda, ada satu indikator (ORI-1: Mengetahui banyak) bernilai sedang (40-60\%), sedangkan sisanya bernilai tinggi (60-80\%) dengan nilai tertinggi pada indikator KEP-3 (mampu menerima saran dan kritikan). Melalui nilai tersebut di atas dapat kita interpretasikan bahwa sikap wirausaha mahasiswa pada perkuliahan bioteknologi bermuatan bioentrepreneurship umumnya terkembangkan dengan baik.

Nilai sikap wirausaha yang lain dijaring melalui penilaian sosialisasi produk, adapun nilai tersebut ditunjukkan sebagai berikut. 


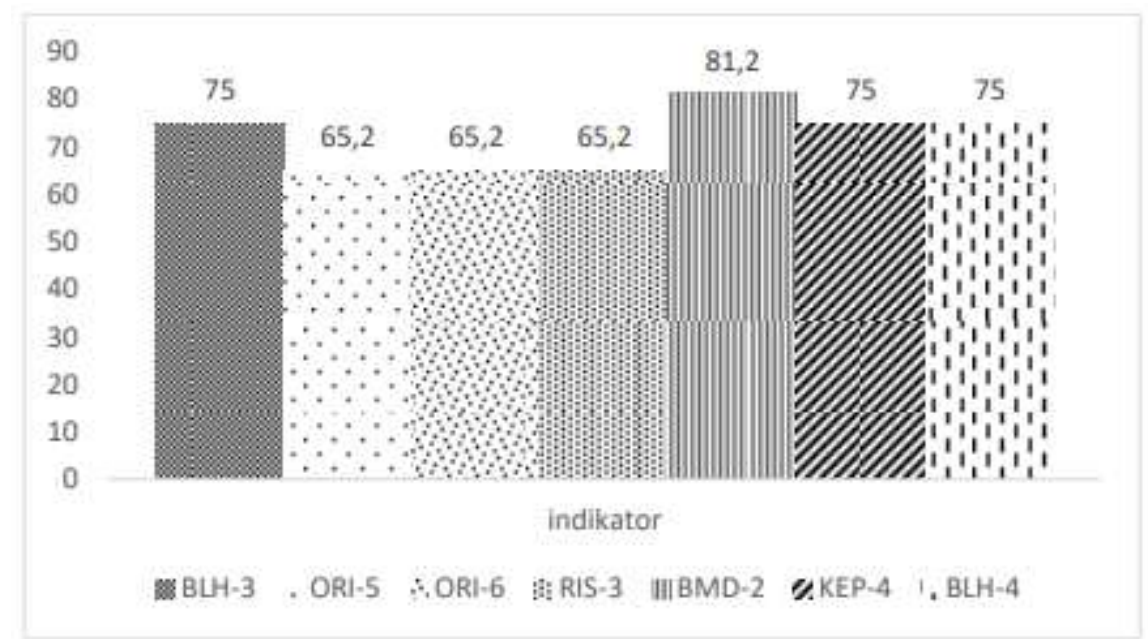

\section{Gambar 2. Nilai sikap wirausaha mahasiswa per indikator melalui penilaian laporan sosialisasi produk}

Sikap wirausaha mahasiswa menunjukkan bahwa rata-rata indikator sikap wirausaha berada pada tinggi $(71,6 \%)$. Nilai antar indikator relatif tidak jauh berbeda, dengan banyak skor yang sama. Ada satu indikator (BMD-2: Mampu mengetahui target pasar) bernilai sangat tinggi $(81,2 \%)$, sedangkan indikator-indikator yang lain bernilai tinggi $(60-80 \%)$ dengan nilai tertinggi pada indikator KEP-3 (mampu menerima saran dan kritikan). Melalui nilai tersebut di atas dapat kita interpretasikan bahwa sikap wirausaha mahasiswa pada perkuliahan bioteknologi bermuatan bioentrepreneurship umumnya terkembangkan dengan baik.

Program Perkuliahan Bioteknologi bermuatan bioentrepreneurship telah memberikan hasil dan temuan dimana sikap wirausaha dan penguasaan konsep mahasiswa seluruhnya terkembangkan dengan baik, yaitu rata-rata terkategori tinggi, yang berarti program bioteknologi bermuatan bioentrepreneurship dapat melatih sikap wirausaha mahasiswa.Hasil studi yang lain juga menunjukkan bahwa bioentrepreneurship dapat meningkatkan keterampilan proses siswa (Mutia \& Tumisem, 2015), dapat meningkatkan sikap wirausaha siswa pada pembelajaran pengetahuan lingkungan (Mulyaningrum, 2014), dan meningkatkan keahlian teknis dan komersial (Collet \& Wyatt, 2005). Sikap wirausaha peserta didik dapat terbangun dengan baik karena program ini dirancang melalui pengintegrasian berbagai keilmuan dengan mempertimbangkan aktivitas mental peserta didik.

Pengintegrasian keilmuan yang dimaksud adalah antara sains/ bioteknologi dengan entrepreneurship/kewirausahaan yang rancangan programnya merupakan adaptasi atau 
pengembangan dari tiga fase pembelajaran dengan teori yang diungkapkan oleh Heidack (Crispeels, 2008) yang menyebutkan bahwa untuk mempertemukan semua aspek yang terkait dengan entrepreneurship, program pendidikan di universitas haruslah berdasarkan kepada konsep tiga fase yang dikemukakan oleh Heidack. Konsep ini tersusun secara berurutan yaitu fase pertama belajar berbasis pengetahuan atau dasar-dasar dalam entrepreneurship, fase kedua mengaplikasikan pengetahuan yang telah diperoleh dalam studi kasus, dan fase ketiga adalah pengetahuan diaplikasikan dan perolehan pengetahuan dari dunia nyata. Hasil studi terdahulu menunjukkan bahwa bioteknologi dapat dipadukan dengan kewirausahaan (Oliver, 2004).Hasil studi lain juga menunjukkan bahwa Bioentrepreneurship dapat diajarkan di universitas, baik sebagai program khusus ataupun program yang terintegrasi dengan mata kuliah, baik untuk tingkat $S-1, S-2$, ataupun $S-3$ (Meyers \& Hurley, 2008; Back 2008, Kjelstrom 2012).Meyers (2007) mengatakan bahwa "Bioentrepreneurship is the process of creating value from life science innovation" atau bioentrepreneurship adalah suatu proses menciptakan suatu nilai tambah dari inovasi ilmu dan teknologi hayati.Collet dan Wyatt (2005) dalam pendidikan bioentrepreneurship mahasiswa haruslah membuat suatu produk bioteknologi berdasarkan ilmu teknis yang dikuasai dan hasil-hasil penelitian yang relevan.

Bagian penting dari kewirausahaan yaitu survey terlebih dahulu untuk melihat peluang penjualan yang bisa dijadikan produksi komersil dan bisa dipasarkan (Witt, et al.2005).Tujuan dari survey atau identifikasi SDL ini adalah untuk membangun kepekaan, karena kepekaan sangat diperlukan dalam mengidentifikasi masalah-masalah setempat, agar siswa dapat berperan sebagai warga negara yang dapat memecahkan isu yang telah diidentifikasi bagaimana sains dan teknologi berdampak di masa depan.

Sikap wirausaha keorisinilan (aspek mengetahui banyak) serta indikator berorientasi tugas dan hasil (aspek mampu mengkalkulasi keuntungan) bernilai sedang dan tinggi, hal ini dikarenakan pada fase 1 pembelajaran membahas tentang Bioentrepreneurship, dimana diajarkan pengetahuan-pengetahuan tentang Bioentrepreneurship. Hal ini sejalan dengan Berglund, et al (2006) bahwa dalam wirausaha atau entrepreneurship ada tiga bagian yang dapat diajarkan yaitu pengetahuan (knowledge), keterampilan (skill), dan sikap (attitude).Pengetahuan memiliki tiga level dasar yaitu info yang didapat disimpan untuk penggunaan dimasa depan. Info diorganisir untuk pencarian keterangan lebih lanjut dan yang terakhir info dimengerti untuk penggunaan yang tepat dan optimal. 
Pada program ini, setelah mahasiswa/peserta didik telah memiliki pengetahuan dan struktur kognitif yang baru, maka mereka diajak untuk menerapkan konsep tersebut menjadi sebuah ide kreatif.Sehingga fase kedua pada program ini adalah fase kreativitas.Yaitu mengaplikasikan skema kognitif yang telah terbentuk menjadi suatu ide dan desain produk bioteknologi berbahan sumber daya lokal.

Sikap wirausaha keorisinilan (inovatif, kreatif, mampu mengemas produk dan menawarkannya secara kreatif), sikap berorientasi masa depan serta sikap berorientasi laba bernilai sedang dan tinggi, hal ini dikarenakan program perkuliahan ini memberikan kesempatan pada peserta didik untuk mengembangkan motivasinya dalam membangun pengetahuan yang sesuai dengan struktur kognitif yang telah dimilikinya dan menggunakan sumber daya setempat yang digunakan dalam memecahkan masalah. Kegiatan memecahkan masalah memberi anak-anak kesempatan untuk menggunakan imajinasi mereka dan mencoba mewujudkan ide-ide mereka (Beetlestone, 2011).

Fase ketiga program ini adalah membuat produk bioteknologi, dimana mereka mewujudkan ide yang telah dimiliki menjadi produk.Fase ini sangat penting karena jika tidak mencipta maka belum dapat disebut memiliki sikap wirausaha.Menurut Ciputra (2009) pendidikan entrepreneur sangat menekankan perilaku mencipta.

Kegiatan merancang dan membuat produk inipun dapat meningkatkan sikap wirausaha,dapat terlihat dari tingginya nilai sikap aspek kepemimpinan,fleksibel dalam membuat produk dan ketekunan bernilai tinggi. Hal ini senada dengan Ciputra (2009) bahwa untuk mengajarkan kewirausahaan, pembelajaran dilakukan secara learning by doing atau menekankan lewat proyek-proyek untuk membuat siswa memahami sikap dan keterampilan yang dibutuhkan untuk menjadi wirausaha yang baik dan sukses. Perlakuan apa pada program sehingga sikap wirausaha mahasiswa meningkat.Mahasiswa membuat produk berdasarkan hasil rancangannya dalam waktu yang terbatas (1 bulan), tetapi dalam perjalanannya proses pembuatan produk tersebut dapat berbeda dengan rancangan jika dinilai lebih baik. Secara umum, produk yang dibuat siswa memiliki kegunaan masingmasing dan dapat menjawab pemecahan masalah dan meningkatkan nilai sumber daya lokal.

Sikap wirausaha kepemimpinan (mudah bergaul, mampu menerima saran dan kritikan orang lain), kepercayaan diri serta pengambilan risiko yang dimiliki mahasiswa tergolong tinggi, hal ini tidak terlepas akibat perlakuan dari fase terakhir atau keempat program ini yaitu sosialisasi, dimana mahasiswa mengumpulkan pandangan masyarakat 
tentang produk yang dihasilkan, baik dari aspek biaya, pemasaran ataupun manfaatnya kemudian dianalisis.Produk yang dihasilkan diuji pasar, untuk diketahui pandangan calon user apakah produk ini layak/tidak? Berguna/tidak?Berapa harga yang cocok untuk produk ini dsb. Melalui kegiatan ini, mahasiswa bisa menghitung modal dan keuntungan yang akan didapat, belajar cara memasarkan, dengan adanya fase ini akan menumbuhkan minat wirausaha mahasiswa.

Berbagai metode serta pendekatan telah diketahui dapat melatih sikap wirausaha mahasiswa dalam bidang sains, yaitu Blending learning (Radu, 2015), TechnoEntrepreneurship (Farzin, 2015), Bioneering (Collet \& Wyatt, 2005), discovery/Inquiry (Ibrohim,2015), Konstruktif-Inquiry (Supartono, 2009), dan EnSciT /Entrepreneural Science Thinking (Buang, 2009). Melalui data diatas, dapat dilihat bahwa seluruh tujuan pembelajaran telah tercapai, terjadi kenaikan nilai mahasiswa pada seluruh indikator tujuan pembelajaran.Sehingga dapat disimpulkan bahwa sikap wirausaha mahasiswa juga dapat memiliki nilai yang tinggi apabila dilatih melalui program bioteknologi bermuatan bioentrepreneurship. Berdasarkan hasil pengamatan kualitatif, maka dapat diajukan beberapa saran agar perkuliahan Bioteknologi bermuatan bioentrepreneurship lebih baik lagi, yakni alokasi waktu, materi yang diajarkan tentang kewirausahaan supaya lebih mendalam, pengenalan model pembelajaran di awal pertemuan, memberikan pembelajaran yang tidak terlalu formal sehingga mahasiswa merasakan suasana yang lebih nyaman, serta menyediakan laboratorium khusus untuk tempat pembuatan produk bioteknologi.

Melalui angket respon, kebanyakan mahasiswa menyatakan bahwa perkuliahan Bioteknologi bermuatan bioentrepreneurship dapat membuat mereka memiliki sikap wirausaha yang baik, lebih menyadari besarnya kaitan antara bioteknologi dengan kewirausahaan, mampu membuat produk dan mensosialisasikannya, serta dapat meningkatkan minat terhadap bioteknologi..Secara umum nilai yang ada telah menunjukkan bahwa sikap wirausaha mahasiswa telah mencukupi sebagai bagi mereka menjadi guru biologi yang berjiwa wirausaha. Perspektif ke depan adalah diperlukannya pendampingan bagi mereka, utamanya setelah mereka mampu menghasilkan produk serta mensosialisasikannya, diperlukan pendampingan supaya produk-produk yang dihasilkan dapat terjual. Produk yang terjual tersebut dapat memberikan manfaat finansial bagi mahasiswa sehingga diharapkan dapat menjaga atau bahkan meningkatkan sikap wirausaha mahasiswa ke depannya. 


\section{KESIMPULAN}

Sikap wirausaha mahasiswa secara umum memiliki nilai yang tinggi apabila dilatih melalui program bioteknologi bermuatan bioentrepreneurship. Nilai yang ada telah menunjukkan bahwa sikap wirausaha mahasiswa telah mencukupi sebagai bagi mereka menjadi guru biologi yang berjiwa wirausaha. Kebanyakan mahasiswa menyatakan bahwa perkuliahan Bioteknologi bermuatan bioentrepreneurship dapat membuat mereka memiliki sikap wirausaha yang baik, lebih menyadari besarnya kaitan antara bioteknologi dengan kewirausahaan, mampu membuat produk dan mensosialisasikannya, serta dapat meningkatkan minat terhadap bioteknologi.

\section{DAFTAR PUSTAKA}

Acquaah, G. 2004. Understanding Biotechnology: An Integrated and Cyber-Based Approach. New Jersey: Prentice Hall

Back, S.M. 2008. The Bioentrepreneurship MBA: Options for mid-tier business schools Journal of Commercial Biotechnology (2009) 15, 183-193

Badan Pusat Statistik.2015. Jumlah wiraswasta Indonesia. [Online]. Tersedia: (http://www.bps.go.id)

Buang, Nor Aishah; Halim, Lilia dan Mohd Meereah, Subahan. 2009. Understanding the Thinking of Scientists Entrepreneurs:Implications for Science Education in Malaysia Journal of TURKISH SCIENCE EDUCATION, 6, 2, August 2009

Ciputra .2010. Quantum Leap: Entrepreneurship Mengubah Masa Depan Bangsa dan Masa Depan Anda. Jakarta: Elex media Komputindo

Collet, C \& Wyatt, D .2005. "Bioneering”-teaching biotechnology entrepreneurship at the undergraduate level. Education + Training 47(6)

Crispeels, T. 2008. Best practices for developing university bioentrepreneurship education programmes. Journal of Commercial Biotechnology, 15, 2, 136-150

Direktorat Pembelajaran dan Kemahasiswaan (BELMAWA) Dirjen Dikti dan ALPTKI. 2013. Dokumen deskripsi umum dan learning outcome 12 prodi LPTK. [Online]. Tersedia: http://lpm.iainbanten.ac.id/po-content/po-upload/LAMPIRAN 3\%20Deskripsi\%20dan\%20Learning\%200utcome\%2012\%20PRODI\%20LPTK.pdf

Farzin, F. 2015. An Investigation into the Impact of Techno-Entrepreneurship Education on Self- Employment. International Journal of Social, Behavioral, Educational, Economic, Business and Industrial Engineering, 9, 3, 2015 
Fraenkel, J \& Wallen, N. 2007. How to Design and Evaluate Research in Education. New York: McGrawHill.

Ibrohim. 2015. PengembanganPembelajaranIpa/Biologi Berbasis Discovery/Inquiry Dan Potensi Lokal Untuk Meningkatkan Keterampilan Dan Sikap Ilmiah Serta Menumbuhkan Jiwa Kewirausahaan. Prosiding Semnas Sains \& EntrepreneurshipIi Hal:1-19

Kjelstrom, J. 2012. The 21st Century Needs Entrepreneurial Scientists and Engineers. [Online].

Tersedia:http://uccs.ucdavis.edu/assets/event-assets/eventpresentations/kjelstrom_presentation

Langer, L.J. 2014. Building a curriculum for bioentrepreneurs.[Online].Tersedia: http://www.nature.com/bioent/2014/140801/full/bioe.2014.9.html

Meyers, A. 2007. Enterprise for Life Scientists: Developing Innovation and Entrepreneurship in the Biosciences. Journal of Commercial Biotechnology (2008) 14, 355-356. doi:10.1057/jcb.2008.21

Meyers, A \& Hurley,P .2008. Bioentrepreneurship educationprogrammes in the United

Mulyaningrum, E. R. 2014. Religion, Environment, Science, AndTechnology (Rest) Pada Pembelajaran Pengetahuan Lingkungan dengan Pendekatan

Mutia, Iin \& Tumisem. 2015. Pembelajaran berbasis Bioentrepreneurship untuk meningkatkan keterampilan proses sains siswa kelas X SMA Muhammadiyah 1 Purwokerto. Prosiding Semnas Sains \& Entrepreneurship II Hal: 34-39

Oliver, Amalya L. 2014. Biotechnology entrepreneurial scientists and their collaborations. Research Policy, 33 (2004), 583-597

Radu, N et al. 2015. Educational Management In The Field Of Life Sciences - Blending Learning For Bioentrepreneurs Training. Scientific Papers Series Management, Economic Engineering in Agriculture and Rural Development Vol. 15, Issue 2.

Witt, Ulrich \& Zellner. C. 2005. Knowledge-based Entrepreneurship: The Organizational Side of Technology Commercialization. Journal of Economic Literature.

York, A.S., McCarthy, K.A \& Darnold, T.C. 2008. Teaming in biotechnology commercialisation: The diversity performance connection and how university programmes can make a difference. Journal of Commercial Biotechnology, 15, 1, 3- 11 